Review

\title{
Climate-Related Prudential Risks in the Banking Sector: A Review of the Emerging Regulatory and Supervisory Practices
}

\author{
Mete Feridun $1, *(1)$ and Hasan Güngör ${ }^{2}$ (1) \\ 1 Department of Banking and Finance, Faculty of Business and Economics, Eastern Mediterranean University, \\ Famagusta, North Cyprus, via Mersin 10, Turkey \\ 2 Department of Economics, Faculty of Business and Economics, Eastern Mediterranean University, \\ Famagusta, North Cyprus, via Mersin 10, Turkey; hasan.gungor@emu.edu.tr \\ * Correspondence: mete.feridun@gmail.com; Tel.: +90-392-630-2127
}

Received: 16 May 2020; Accepted: 22 June 2020; Published: 1 July 2020

\begin{abstract}
This article reviews emerging regulatory and supervisory practices with respect to prudential risks from climate change in the banking sector. It evaluates the theoretical considerations with respect to climate-related financial risks in the banking sector, reviews the related academic literature, and analyzes the policy-related publications from various regulatory authorities. As a result of this assessment, the article concludes that the major regulatory and supervisory expectations can be categorized into four key areas: (i) board-level attention to climate risks and integrating them into internal governance frameworks, (ii) embedding climate risks into strategies and overall risk management frameworks, (iii) identifying climate-related material exposures and disclosure of relevant key metrics, and (iv) assessing capital impact from climate risk through scenario analysis and stress testing. The article also presents a number of implications for banks and banking regulators in other jurisdictions to help them identify the actions required to address climate change risks in the banking sector.
\end{abstract}

Keywords: climate change; climate risk; risk management; banking regulation

\section{Introduction}

Climate-related financial risks have started to intensify both at the micro and macro levels over the last decade. At the micro level, these already pose a threat to the safety and soundness of banks, insurers, and the wider financial system. At the macro level, on the other hand, they pose a significant threat to the stability of the financial system. For instance, it is estimated that the total annual economic costs around the world from natural disasters have frequently exceeded the 30-year average of $\$ 140$ billion in the last ten years and the number of extreme weather events has increased more than $300 \%$. Climate-related claims burden is expected to increase up to over $100 \%$ by 2085 in the insurance sector due to more frequent climate events and sea level rise [1].

This has important implications for the financial system. Given increased instances of extreme weather events and shifts in climate patterns, these risks have the potential to intensify in the foreseeable future. Therefore, addressing climate-related financial risks within the existing regulatory and supervisory frameworks has gained more importance over the last few years, with increasing supervisory expectations for banks in some countries to actively identify and manage their climate-related risks [2].

Parallel to this, academic research has also recently begun focusing on the risks from climate change for banks (see, inter alia, [3-5]) and the transition costs on banks (see, inter alia, [6,7]). On the 
other hand, a few recent studies (see, inter alia, [8-10]) have explored the financial stability aspects of climate change.

However, an important gap remains in the existing academic literature in terms of an up-to-date review of the regulatory and supervisory approaches with respect to prudential risks from climate change in the banking sector. It is against this backdrop that this article explores the international and national regulatory and supervisory agendas with respect to managing climate change-related prudential risks in the banking sector in light of the existing theoretical and empirical literature.

The rest of the article is structured as follows: The next section will explore the theoretical considerations on the financial impact of climate change in the banking sector. Section 3 will provide a brief review of the relevant academic literature. Section 4 will undertake a review of the emerging regulatory and supervisory approaches with respect to the management of climate change-related financial risks. Section 5 discusses the impact of climate change mitigation policies and regulatory expectations on banks. The final section will present the conclusions and the policy implications that emerge from the article.

\section{Theoretical Considerations on the Financial Impact of Climate Change in the Banking Sector}

From a theoretical perspective, financial risks from climate change include transition risks that may arise from a transition to a low-carbon economy and physical that risks that may arise from unexpected shifts in climate patterns, both of which may have far-reaching ramifications for the banking sector.

Physical risk channels through which climate-related financial risks may transmit into the market values of equity and debt instruments include reduced revenue from decreased production capacity, lower sales, increasing operating costs, increased capital costs, direct damages from climate change, and write-offs of assets situated in high risk locations.

Transition risks, on the other hand include factors such as higher carbon prices, limits on emissions, and subsidies to carbon-intensive technologies, as well as a ban on certain products or technologies. These risks emerge due to adjustment towards a carbon-neutral economy and may result in drastic falls in asset values and energy prices, distorting the dynamics of the banking sector balance sheets [11].

The Prudential Regulation Authority (PRA) considers that the physical and transition risk factors from climate change have distinctive aspects that can be summarized as in Table 1 below. These aspects are also relevant from a financial stability perspective, in addition to bank-level considerations. As can be seen from the table, financial risks from climate-related factors can have far-reaching breadth and magnitude, are usually uncertain in nature, and are broadly foreseeable [12].

Table 1. Distinctive Elements of the Financial Risks from Climate-related Factors.

\begin{tabular}{ll}
\hline Element & Description \\
\hline Far-reaching in breadthand magnitude & $\begin{array}{l}\text { The financial risks from physical and transition risk factors are relevant } \\
\text { to multiple lines of business, sectors, and geographies. Their full impact } \\
\text { on the financial system may therefore be larger than for other types of } \\
\text { risks, and is potentially non-linear, correlated, and irreversible. }\end{array}$ \\
\hline Uncertain and extendedtime horizons & $\begin{array}{l}\text { The time horizons over which financial risks may be realized are } \\
\text { uncertain, and their full impact may crystallize outside of many current } \\
\text { business planning horizons (tragedy of the horizon). Using past data } \\
\text { may not be a good predictor of future risks. }\end{array}$ \\
\hline Foreseeable nature & $\begin{array}{l}\text { While the exact outcome is uncertain, there is a high degree of certainty } \\
\text { that financial risks from some combination of physical and transition } \\
\text { factors will occur. }\end{array}$ \\
\hline Dependency on short-term actions & $\begin{array}{l}\text { The magnitude of future impact will, at least in part, be determined by } \\
\text { the actions taken today. This includes actions by governments, financial } \\
\text { market participants, and a range of other actors. }\end{array}$ \\
\hline
\end{tabular}


The PRA considers some of these risks to be "potentially non-linear, correlated, and irreversible" [13]. Therefore, banks are required to address these risks, taking into account how they can pose credit, market, and operational risks in the short, medium, and long run. Furthermore, the PRA considers that the impact of these risks will by and large depend on short-term policy actions and they present banking regulators and central banks with unique challenges, as they have unique and distinctive characteristics separating them from other types of financial stability risks. Therefore, it is evident that the identification, assessment, and management of these risks require a holistic, strategic, and concerted effort from all central banks, regulators and financial institutions.

\subsection{Physical Risks That may Arise from Shifts in Climate Patterns}

Banking regulators, and academic researchers generally agree that physical risks such as increased instances of extreme weather events and shifts in climate patterns can pose a threat to the banking sector. These climate-related factors may result in damage to physical assets and commodities, disruption to business activity and profitability, and reduction in income levels of households, prompting financial losses in the banking sector [14].

Table 2 includes an indicative list of physical risks that may arise from shifts in climate patterns complied from the Bank of England (BoE) [15], and the Task Force on Climate-related Financial Disclosures (TCFD) [16]. As can be seen in the table, acute physical risks such as heatwaves, floods, wildfires, and storms may particularly pose financial risks to banks offering commercial mortgages or loans to industries or sectors which are sensitive to climate change. On the other hand, physical risks such as increased instances of extreme weather events and shifts in climate patterns may result in a fluctuation in commodity and energy prices, prompting a reassessment of asset values, the impact of which might be substantial on derivative contracts, corporate bonds, and equities, particularly for banks with large trading books.

Table 2. Indicative Lists of Transitional and Physical Risks.

\begin{tabular}{ll}
\hline Physical Risks & Transitional Risks \\
\hline Changes in temperature & Higher carbon prices \\
Water scarcity and extended droughts & Limits on carbon emissions \\
Cyclones, hurricanes, and typhoons & Higher taxes on carbon-intensive technologies \\
Floods in residential areas and farmlands & Subsidies to low-carbon alternatives \\
Sea level rise in coastal areas & Ban on carbon-intensive products \\
Wildfires that affect populated areas & Ban on carbon-intensive technologies \\
\hline
\end{tabular}

Source: Compiled from [14-16] by the authors.

In particular, sea level rise and floods may impair asset values, increase credit risks, and reduce the value of investments held by banks. Flood risk could be very severe for both residential and commercial mortgage portfolios in certain geographical locations, where credit risk on banks' loan books may increase substantially through greater loss given default and probability of default numbers [17]. Rises in the sea level, on the other hand, have the potential to impact prices of coastal properties over time, increasing credit risks for banks just like in the case of flood risks. Similarly, rising temperatures may also affect the agricultural sector, as well as destruction of residential and commercial real estate and other infrastructure due to increased risk of fires [18].

Increasing severity and frequency of climate-related events may pose credit, market and operational risks to banks. There could also be risks to business continuity, such as outsourced critical functions that might be exposed. This requires banks to monitor their climate change risks on an ongoing basis to ensure that their capital sources remain sufficient.

The nature and extent of the physical risks to banks that may arise from shifts in climate patterns are well-supported by academic research [19]. The existing literature particularly documents empirical evidence that climate change increases the default risk of borrowers and amplifies macro-financial risks [20]. 


\subsection{Transition Risks from Adjustment towards a Carbon-Neutral Economy}

Transition risks due to adjustment towards a carbon-neutral economy, on the other hand, are shorter-term in nature. However, they have an intensifying potential to impact the banking sector and the broader financial sector through various channels. These transition risk channels include changes in regulatory policy, changes in technology, and changes in market preferences.

Table 2 includes an indicative list of transitional risks that may arise from shifts in climate patterns. As can be seen from the table, these risks may drive changes in the value of assets and liabilities on banks' balance sheets. For instance, regulatory policies may increase the price of carbon emissions, the impact of which on commodity prices, derivatives contracts, and equities may be substantial. These balance sheet effects will be more drastic in the case of banks with material trading books. Therefore, banks are required to actively assess their investment and loan portfolios.

The existing literature, which focuses on the transition period towards a carbon-neutral economy, offers predictions that the value of some assets will decline substantially, while the value of others which are more climate-friendly will increase (see [5,19]). The literature discusses that there can be severe potential financial losses from investments losing value during the transition period due to "stranded asset risks", where coal reserves may lose value as a result of shifting investor preferences towards greener products and technologies [20].

The industry and the regulators, on the other hand, are more concerned that the adjustment towards a carbon-neutral economy may result in changes in the transportation market through the use of low-carbon fuels, changes in energy storage costs, and fluctuations in energy prices. The regulators are particularly concerned that these may prompt a reassessment of asset values, which will have a more drastic impact on the balance sheets of those banks whose business model is focused on energy trading.

On the other hand, the transition to a lower-carbon economy may have a substantial impact on business models and creditworthiness of borrowers, which means that banks with exposure to clients in these sectors should factor in the loss in their loan repayment capacities as per the BCBS' principles for the management of credit risk $[6,7,17]$.

\section{Review of the Academic Literature}

There is a small body of literature which focuses on the financial risks from climate change in the banking sector due to shortage of empirical evidence. The existing literature focuses almost entirely on the sustainability and corporate social responsibility aspects of climate change in the context of the banking sector (see [21-28]).

However, the number of studies exploring the impact of financial risks from climate change on banks' balance sheets is limited. [29] provide a quick summary of the existing literature until 2015. The same authors also presented a methodological framework for assessing the climate change related risks in the banking sector. Other than this study, a very small number of studies have explored the role of environmental factors in lending by banks (see [30-39]).

With respect to the physical risks from climate change for banks, only a few studies (see [3-5]) have explored the risks from weather-related disasters on banks, whereas a few others have focused on the transition costs on banks' balance sheets (see [6,7]). On the other hand, a few recent studies have explored the wider financial stability implications of climate change risks. Some of these studies focused on economic and stress testing models.

More recently, a growing strand of the related literature has focused on the disclosure of climate risks by banks [40,41] and pricing behavior of banks [42], while others have explored various topics with respect to green investments, green bond issuance, and related securitization efforts by banks [43-45].

The purpose of this article is not to provide an extensive analysis of the related literature. However, as evident from this quick review of the existing studies, the literature clearly lacks a study that reviews the progress of the prudential banking regulations with respect to climate change risks. The present 
article aims to make a contribution to the literature by filling this important gap and summarizing what banks are expected to do.

\section{Emerging Regulatory and Supervisory Expectations with Respect to Climate-Related Financial Risks}

Prioritizing shorter-term, more immediate issues, such as Basel III implementation, both the Basel Committee on Banking Supervision (BCBS) and the national regulators have generally been late to respond to climate change risks. However, in recent years many central banks and financial regulators across the world have been increasingly acknowledging that financial risks from climate change are a threat to financial stability. As a result, a number of global regulatory initiatives have started to take shape over the last few years in response to intensifying climate-related financial risks.

\subsection{Emerging Global Regulatory and Supervisory Expectations}

For instance, the BCBS set up a high-level Task Force on Climate-related Financial Risks (TFCR) to undertake specific initiatives on climate-related financial risks. The TFCR has mainly focused on the supervisory treatment of climate-related financial risks, identifying a number of supervisory guidelines, action plans, and supervisory statements related to the governance, strategy, and/or risk management of climate-related financial risks by banks.

In 2020, TFCR undertook a stock take of members' existing regulatory and supervisory initiatives on climate-related financial risks through a questionnaire. The findings of the questionnaire show that the majority of BCBS members consider climate-related financial risks important and that have already started doing work with respect to the measurement of these risks. The questionnaire also revealed that around two-fifths of members have issued, or are in the process of issuing, supervisory guidance with respect to climate-related financial risks [46]. Based on this survey, the BCBS has identified the key supervisory expectations on climate-related financial risks from its member jurisdictions as:

- Outlining supervisory plans on deliverables and activities related to climate change risks;

- Encouraging financial institutions to take actions in governance, risk management, and disclosure of climate-related exposures and financial risks;

- Providing guidance on how to properly integrate climate-related financial risks within risk management;

- Requiring banks to increase credit availability to 'green' and 'low carbon' sectors.

On the other hand, at the global level, a network called the Network for Greening the Financial System (NGFS) has also been established by the central banks and regulators to address climate risks in the banking sector and to prompt banks to start embedding the management of climate change risks into their enterprise risk management frameworks and processes. In 2020, NGFS issued guidelines for supervisors with respect to integrating climate-related and environmental risks into prudential supervision [47]. In addition, the Financial Stability Board (FSB) has established the TCFD, an industry-led task force to identify the public disclosure of climate-related financial risks under Basel III Pillar 3 framework. Supporters of this initiative include prominent global banking groups such as BNP Paribas, UBS, HSBC, Credit Agricole, and Société Générale [48].

The International Monetary Fund has also recently expressed its support to these efforts. It plans to contribute to the understanding of the macro-financial transmission of climate risks by improving its stress tests within its Financial Sector Assessment Program. The IMF is also a member of the NGFS, actively contributing to the group's efforts to integrate climate-related risks into financial supervision and financial stability monitoring $[49,50]$. 
In the European Union (EU), on the other hand, the main impetus has been the European Banking Authority's (EBA) 2019 Action Plan on Sustainable Finance. The plan outlines the EBA's approach and timeline for delivering the mandates in response to the European Commission's (EC) Action Plan, covering key metrics, risk management, scenario analysis, and adjustments to risk weights [51]. In the same year, the EU reached a political agreement on the Sustainable Finance Taxonomy Regulation, which aims to support environmentally sustainable economic activities [52]. In addition, the EC announced its Sustainable Europe Investment Plan in 2020, which is intended to support the transition to a climate-neutral and green economy [53].

\subsection{Emerging National Regulatory and Supervisory Expectations}

As can be seen in Table 3, in many countries around the world, regulatory authorities have already incorporated climate risk into their supervisory approaches, actively encouraging banks to consider climate risks within their wider risk-management frameworks. As summarized in the table, in many countries regulatory authorities have already started encouraging or requiring climate-related financial disclosures, as well as developing frameworks for green finance.

On the other hand, in countries such as the Netherlands and the United Kingdom (UK), stress testing banks for climate risks have already been on the top of the regulatory agenda. In other countries, central banks and regulatory authorities have announced roadmaps and strategies to align their banking sector with sustainable developments and to ensure that the transition to a low-carbon economy does not adversely impact financial stability.

A few national regulators have also started to require evidence that banks are adequately assessing their climate-related risks and that they are thinking carefully about the impacts these risk could have on their business and operations, asking banks to consider how their capital would be affected in different physical and transition climate risk scenarios in their internal capital adequacy assessments, known as the Internal Capital Adequacy Assessment Process (ICAAP).

In particular, financial regulators in the UK have generally acted much faster than their peers in other developed countries. The BoE, the PRA, and the Financial Conduct Authority (FCA) have already started addressing these risks. While the PRA has been focusing on the mitigation of prudential risks from climate change, the FCA has been focusing on promoting green finance. The BoE, on the other hand, has been dedicating its efforts to maintaining financial stability through stress testing banks with respect to climate change risks.

The PRA and FCA also set up the Climate Financial Risk Forum (CFRF) in 2019 to encourage industry participants to develop approaches to managing climate risk. The forum, which comprises leading financial institutions, including BNP Paribas, HSBC, JP Morgan, and RBS, has already started working on disclosure requirements, scenario analysis, and risk management with respect to climate risks. In 2020, the CFRF published a guide for the industry on how they should address climate-related financial risks [54]. The UK government has also been actively leading the global green finance initiative since the announcement of its "Green Finance Strategy" in 2019 [55].

In many other countries, central banks and regulators have been slower to respond to climate-related financial risks. However, supervisors have started expressing their supervisory expectations that banks should incorporate climate risks into their internal risk management frameworks. In the USA, for instance, regulators including the Commodity Futures Trading Commission and the Securities and Exchange Commission have begun to expect banks to provide investors with consistent, reliable, and comparable disclosures with respect to climate risks, in line with the TCFD recommendations. 
Table 3. Emerging International Trends and Guiding Principles Regarding Climate Risks.

\begin{tabular}{|c|c|c|}
\hline Country & Relevant Authority & Regulatory or Supervisory Expectation \\
\hline Australia & $\begin{array}{l}\text { Australian Prudential } \\
\text { Regulation Authority }\end{array}$ & $\begin{array}{l}\text { Banks are encouraged to consider climate risks within } \\
\text { their wider risk-management frameworks. In } 2019 \text {, they } \\
\text { conducted a survey of financial firms to gauge their } \\
\text { awareness of climate risk and identify industry } \\
\text { best practice. }\end{array}$ \\
\hline Bangladesh & The Bangladesh Bank & $\begin{array}{l}\text { Updated Environmental Risk Management Guidelines } \\
\text { were issued in } 2017 .\end{array}$ \\
\hline Brazil & The Central Bank of Brazil & $\begin{array}{l}\text { A Resolution on Social and Environmental Responsibility } \\
\text { for Financial Institutions was issued in } 2014 .\end{array}$ \\
\hline Canada & The Bank of Canada & $\begin{array}{l}\text { Climate change risk has been included in the analysis of } \\
\text { the Canadian financial system. It has also published a } \\
\text { Climate Change Scenario Analysis study in } 2020 \text {. }\end{array}$ \\
\hline China & $\begin{array}{l}\text { The China Banking } \\
\text { Regulatory Commission }\end{array}$ & $\begin{array}{l}\text { The Green Credit Guidelines were issued in } 2012 \text { as well } \\
\text { as the Green Credit Statistics System and Key } \\
\text { Performance Indicators in } 2014 \text {. }\end{array}$ \\
\hline Colombia & Colombian Banking Association & $\begin{array}{l}\text { The Colombia Green Protocol was signed in } 2012 \text { and the } \\
\text { Guideline on Environment and Sustainability Risk } \\
\text { Management was launched in } 2016 \text {. }\end{array}$ \\
\hline Ecuador & $\begin{array}{l}\text { The Banking Association } \\
\text { of Ecuador }\end{array}$ & The Sustainable Finance Protocol was signed in 2016. \\
\hline EU & $\begin{array}{l}\text { The European Commission andthe } \\
\text { European Banking Authority }\end{array}$ & $\begin{array}{l}\text { The adoption of a Green Supporting Factor is under } \\
\text { discussion. Member states are supportive as per their } \\
\text { commitment to the energy transition. It is also being } \\
\text { assessed whether a specific prudential regulation should } \\
\text { be implemented for green assets. }\end{array}$ \\
\hline Indonesia & $\begin{array}{l}\text { The Indonesia Financial } \\
\text { Services Authority }\end{array}$ & $\begin{array}{l}\text { The Roadmap for Sustainable Finance was published } \\
\text { in } 2014 .\end{array}$ \\
\hline Kenya & Kenya Bankers Association & $\begin{array}{l}\text { The Sustainable Finance Initiative Guiding Principles } \\
\text { were announced in } 2015 .\end{array}$ \\
\hline Mexico & Mexican Banking Association & The Sustainability Protocol was signed in 2016. \\
\hline Morocco & The Central Bank of Morocco & $\begin{array}{l}\text { The Roadmap for Aligning the Moroccan Financial Sector } \\
\text { with Sustainable Developments was announced in } 2016 .\end{array}$ \\
\hline Netherlands & The De Nederlandsche Bank & $\begin{array}{l}\text { Climate risk has been incorporated into supervisory } \\
\text { framework and stress testing. The first climate-related } \\
\text { stress testing was conducted in } 2018 \text {. }\end{array}$ \\
\hline New Zealand & The Reserve Bank of New Zealand & $\begin{array}{l}\text { A Climate Change Strategy was announced in } 2018 \text { to } \\
\text { ensure that New Zealand's transition to a low-carbon } \\
\text { economy does not adversely impact financial stability. }\end{array}$ \\
\hline Nigeria & The Central Bank of Nigeria & $\begin{array}{l}\text { The Nigerian Sustainable Banking Principles were } \\
\text { published in } 2012 .\end{array}$ \\
\hline Peru & $\begin{array}{l}\text { The Superintendency of Banking, } \\
\text { Insurance and Private Pension } \\
\text { Fund Administrators of Peru }\end{array}$ & $\begin{array}{l}\text { The Regulation for Social and Environmental Risk } \\
\text { Management was announced in } 2015 .\end{array}$ \\
\hline Singapore & $\begin{array}{l}\text { The Monetary Authority } \\
\text { of Singapore }\end{array}$ & $\begin{array}{l}\text { Banks are required to integrate sustainability risks into } \\
\text { their risk management frameworks. The regulator plans } \\
\text { to include climate-related scenarios in industry-wide } \\
\text { stress tests. }\end{array}$ \\
\hline South Africa & Banking Association South Africa & $\begin{array}{l}\text { Voluntary Principles on Environmental and } \\
\text { Sustainability Risk Management were published in } 2014 .\end{array}$ \\
\hline
\end{tabular}


Table 3. Cont.

\begin{tabular}{lll}
\hline Country & Relevant Authority & Regulatory or Supervisory Expectation \\
\hline Turkey & Banks Association of Turkey & $\begin{array}{l}\text { Voluntary Sustainability Guidelines were published } \\
\text { in 2014. }\end{array}$ \\
\hline UK & $\begin{array}{l}\text { The Prudential Regulation } \\
\text { Authority (Bank of England) }\end{array}$ & $\begin{array}{l}\text { Climate risk have already been incorporated into } \\
\text { prudential supervisory framework in 2019. Climate risk } \\
\text { scenarios will be included in the sector-wide stress tests } \\
\text { as part of the 2021 exploratory scenario. }\end{array}$ \\
\hline USA & $\begin{array}{l}\text { The Commodity Futures Trading } \\
\text { Commission and the Securities } \\
\text { and Exchange Commission }\end{array}$ & $\begin{array}{l}\text { Supervisors have started expressing their supervisory } \\
\text { expectations that banks should incorporate climate risks } \\
\text { into their internal risk management frameworks } \\
\text { have begun to expect disclosures with respect to } \\
\text { climate risks. }\end{array}$ \\
\hline Vietnam & The State Bank of Vietnam & $\begin{array}{l}\text { The Directive on Promoting Green Credit and Managing } \\
\text { Environmental and Social Risk in Lending Activities was } \\
\text { published in 2015. }\end{array}$ \\
\hline
\end{tabular}

Source: Compiled from [56-58] by the authors.

As climate-related financial risks continue to intensify, regulatory authorities are set to increase the rigor of banks' public disclosure, capital planning, and governance processes to ensure they manage their relevant exposures in a prudent manner. This requires banks to adopt a proactive approach and start preparing as soon as possible. Based on the analysis of the regulatory developments to date, four key areas have emerged that banks are recommended to focus on:

- Board-level attention to climate risks and integrating them into internal governance frameworks

- Embedding climate risks into strategies and overall risk management frameworks

- Identifying material exposures to climate risks and disclosure of relevant key metrics

- Assessing capital impact from climate risks through scenario analysis and stress testing

The next section will review these areas in more detail, discussing what banks and banking regulators in other jurisdictions should do. While banks should focus on these four areas, supervisory authorities should start thinking carefully about the country-specific climate risks that they should address in their engagements with the banking sector. This will require them to collect feedback from the industry through surveys, as in the case of the PRA in the UK.

The PRA's 2019 survey on the impact of climate change on the UK banking sector could serve as a good example for other national regulators. The survey was informed by the BoE's wider climate-related work in the UK and globally, so it may serve as a model to banks and regulators in other jurisdictions [13]. Survey questions are provided in Appendices A and B for quick reference. The PRA explains that the survey questions were prepared based on the analysis and insights gained from the PRA's bilateral meetings with firms and other stakeholders. The results of the survey, which covered around $90 \%$ of the banking sector in the UK, suggest that the majority of banks in this jurisdiction do not consider financial risks from climate change simply as corporate social responsibility issues and take them very seriously [13].

\subsection{Prudential Risks from Climate Change and Proposed Measures}

As summarized in Table 4, climate-related risks are in fact drivers of conventional prudential risk types, including credit, market, liquidity, and operational risks. To address climate change risks, various prudential measures have been proposed to date. However, neither BCBS nor national regulators have introduced any binding prudential measures. While the BCBS's Principles for the Management of Credit Risk generally expect banks to identify and analyze risks with respect to any product or activity, the existing prudential framework does not address such risks. In fact, it could even be argued that it disincentivizes long-term green financing by applying a more rigorous capital treatment for long-term loans. 
Table 4. Climate-Related Risks as Drivers of Prudential Risk Categories.

\begin{tabular}{ll}
\hline Risk type & Examples of Climate-related Factors Affecting Prudential Risks \\
\hline Credit risk & $\begin{array}{l}\text { The destruction of a production site by wildfire can increase the probability } \\
\text { of default of the company operating the site. Loss stemming from default of } \\
\text { mortgage-backed loans can increase when the value of buildings provided } \\
\text { as collateral decreases due to new energy-efficiency standards. }\end{array}$ \\
\hline & $\begin{array}{l}\text { Extreme weather events can have an impact on financial institutions' } \\
\text { business continuity through, for instance, damage affecting critical } \\
\text { functions of the financial entity or of its main providers. Financial } \\
\text { institutions or their customers might face a liability charge from parties who } \\
\text { have suffered losses from physical and transition effects and seek to recover } \\
\text { these losses from those they view as responsible. }\end{array}$ \\
\hline Market risk & $\begin{array}{l}\text { Severe weather events or political measures regarding the transition could } \\
\text { lead to re-pricing of financial instruments and corporate debt, affecting the } \\
\text { value of securities held on financial institutions' balance sheets (and/or the } \\
\text { value of collateral used in some operations). The introduction of a carbon } \\
\text { tax can result in investment losses and lower assets' values (stranded assets). }\end{array}$ \\
\hline $\begin{array}{l}\text { A lack of reliable and comparable information on climate-sensitive } \\
\text { exposures of financial institutions could create uncertainty and cause } \\
\text { procyclical market dynamics, including fire sales of carbon-intensive assets, } \\
\text { and potentially also liquidity problems. }\end{array}$ \\
\hline \multicolumn{1}{c}{ Source: [1]. }
\end{tabular}

The idea of incorporating environmental impacts into the calculation of risk-weighted assets has been gaining popularity in recent years. It has been argued that BCBS should provide specific risk weights for exposures to climate risks and carbon risk industries, require banks to hold more assets to cover related risks, and discourage banks from lending to those industries. However, there remain design and operational challenges with respect to integrating climate risks into banks' capital requirements. As discussed by [56], proposals with respect to the integration of climate-risks into banks' capital requirements comprise Green Supporting Factor (GSF), Brown Penalizing Factor (BPF), and Green Weighting Factor (GWF). These proposals aim to discourage carbon intensive loans and support climate-friendly activities.

GSF proposes to incentivize banks to grant credit to green activities by relieving capital requirements for climate-friendly projects. However, this could result in a decrease in banks' capital base vis-a-vis current capital requirements through a creating a "green bubble" where a quick adjustment of lean portfolios towards green loans may lead to a cliff effect in capital requirements. It has been argued that this capital relief may weaken banks' capital adequacy, ultimately threatening financial instability. In the absence of any academic research on the risk level of green credits or on the impact regarding green lending increase, the potential impact of GSF remains uncertain.

BPF proposes to strengthen banks' capital base to help them overcome unexpected losses coming from "brown activities", i.e., high-carbon activities. The idea is to increase capital requirements on brown activities to compensate the capital relief for green assets. It is argued that this would help maintain "capital neutrality". However, in the absence of empirical evidence, the effectiveness of this proposal remains unknown. Therefore, academic research is required to identify if higher capital requirements through BPF will have a significant impact on bank loans to brown activities.

GWF, on the other hand, proposes to accelerate the greening of banks' portfolios, incentivizing green loans by combining GSF and BPF. It proposes to adjust the analytical capital allocation to the degree of sustainability of each asset according to its climate and environmental impacts at the bank level. However, as is the case with GSF and BPF, there is not any empirical research on the impact on regarding green and brown lending. As a result, the effectiveness of this policy also remains questionable. 
Despite these proposals, there is no climate-related prudential regulation with respect to capital requirements in any country to date. In particular, climate-related risks have not been incorporated in the risk-weighted assets. Given climate-related risks remain extremely difficult to quantify due to the lack of forward-looking data, finalizing prudential banking regulations remains a major challenge for regulators.

\section{Impact of Climate Change Mitigation Policies and Regulatory Expectations on Banks}

As climate change has started to transform banking and banking supervision in many countries, it is becoming increasingly fundamental for the banking sector to understand, identify, and address climate-related financial risks. While climate risk drivers may impact banks' credit risk, market risk, and operational risk profiles, evolving regulatory expectations pose operational, strategic, or reputational risks. Furthermore, to assess the potential impact of climate risks on their businesses and borrowers, banks are expected to adopt forward-looking scenario analysis and stress-testing.

Therefore, it has become for important banks to start to incorporate climate change into their risk management frameworks and strategic planning, by assessing their current loan portfolios and banking operations for any physical and transition impacts. Therefore, banks should start to improve the accuracy of information available on climate risks and developing internal systems to manage and monitor climate risk. In recent years, there is also an expectation from banks to adapt a responsible and sustainable banking model to make societies resilient to environmental shocks. This introduces another layer of challenge and complexity to banks' strategies and risk management.

\subsection{Board-Level Attention to Climate Risks and Integrating them into Internal Governance Frameworks}

Banks in the UK are expected to integrate climate change-related financial risks into their internal governance and risk management processes, evidencing this in their risk management policies and processes, management information, and board risk reports. In addition, board-level attention to climate risks is now an important regulatory expectation. The PRA now expects banks' boards to understand and assess the financial risks from climate change that may affect the firm's operations and balance sheet. In particular, banks are expected to address and oversee these risks from within the firm's overall business strategy and risk appetite [14].

Furthermore, the PRA requires banks to embed the consideration of the financial risks from climate change in their governance arrangements. This requires banks to ascertain that their boards have the right information, knowledge, and tools with clear accountability for climate within the board and sub-committees to ensure an orderly transition to a lower-carbon economy. Banks are particularly required to ensure that their boards are supplied with a sufficient amount of high-quality, relevant management information with respect to climate risks to enable them to debate and take decisions in an informed way.

As a result, banks are expected to formally modify enterprise-wide risk appetite statements to acknowledge climate risks, as well as adopting granular climate reporting at the board level [14]. Table 5 below provides PRA's examples of strategic actions being taken by banks to address financial risks from climate change.

As can be seen from the table, the PRA considers climate-related financial risks to be sufficiently material to be considered at the board level. It expects banks to allocate responsibility for identifying and managing financial risks from climate change to an existing Senior Management Function(s) under the Senior Managers \& Certification Regime (SM\&CR), which have been in effect in the UK since 2016.

In the spirit of the SM\&CR principles, the PRA expects banks to define clear responsibilities and accountabilities within their internal governance frameworks, ensuring that they have in place clear ownership of the climate change-related financial risks as well as the overall responsibility for setting the strategy, targets, and risk appetite relating to these risks at board level. In practice, this requires senior management to assign the responsibility for the oversight of climate risks to an existing Senior 
Management Function under the SM\&CR. In fact, the findings of the PRA's aforementioned survey have indicated that the majority of the banks in the already satisfy this supervisory expectation [13].

Table 5. Examples of Actions Being Taken by Firms with a Strategic Approach.

\begin{tabular}{|c|c|}
\hline Example Action & What Should Firms Do? \\
\hline $\begin{array}{l}\text { Deepening understanding of the financial risks from } \\
\text { climate change }\end{array}$ & $\begin{array}{l}\text { Engage with clients to understand the risks } \\
\text { clients face over the longer-term } \\
\text { Publicly support enhanced climate-related } \\
\text { financial disclosures } \\
\text { - Consider how to classify and identify assets to } \\
\text { enable climate-related risk analysis } \\
\text { across portfolios } \\
\text { Use scenario analysis and forward-looking data } \\
\text { to assess the longer-term financial risks }\end{array}$ \\
\hline Agreeing a board-level firm-wide strategic response & $\begin{array}{l}\text { - Review board-level responsibilities to respond } \\
\text { to, and manage, the financial risks from } \\
\text { climate change } \\
\text { - Consider whether the current and future } \\
\text { financial impacts from climate change have been } \\
\text { factored into the firm's risk appetite }\end{array}$ \\
\hline $\begin{array}{l}\text { Considering how decisions today affect future } \\
\text { financial risks }\end{array}$ & $\begin{array}{l}\text { Begin to integrate climate-related risk factors } \\
\text { into forward-looking assessments } \\
\text { Develop a comprehensive, firm-wide } \\
\text { framework for climate-related risk management }\end{array}$ \\
\hline
\end{tabular}

\subsection{Embedding Climate Risks into Strategies and Overall Risk Management Frameworks}

In the UK, banks are expected to identify, measure, and manage their credit risk, market risk, and operational exposures to financial risks from climate change through their risk management frameworks, as well as taking these risks into account within their business strategies, internal processes, and risk appetites. In other words, they should embed financial risks from climate change into their risk management frameworks, policies, and procedures. The PRA specifically expects banks to assess the impact of the financial risks from climate change on their overall risk profiles, business models, and long-term profitability. Table 6 provides examples from the PRA's approach to climate-related risk factors in terms of credit, market, and operational risks [14].

As can be seen from the table above, the PRA considers both physical and transitional risks important for banks' prudential regulation. The regulator expects banks under its supervision to take a strategic, holistic, and long-term approach, carefully assessing how climate-related risks may impact their risk profiles. This essentially means that banks are expected to approach climate risk in the same way that they approach any other financial risks that they are exposed to.

Therefore, banks are required to undertake a thorough assessment of the climate change risks in their investment and loan portfolios on an ongoing basis, as well as on their critical outsourcing arrangements. Some examples of actions that banks have been taking so far include the identification and monitoring of mortgage concentrations in high-risk areas, establishing prudent risk limits, and constraining exposures to carbon-intensive industries. 
Table 6. Examples of Climate-related Financial Risks.

\begin{tabular}{llll}
\hline Risk & \multicolumn{1}{c}{ Credit risk } & \multicolumn{1}{c}{ Market risk } & \multicolumn{1}{c}{ Operational risk } \\
\hline \multirow{2}{*}{ Physical risk } & $\begin{array}{l}\text { Increasing flood risk to mortgage } \\
\text { portfolio;Declining agricultural } \\
\text { output increases default rates }\end{array}$ & $\begin{array}{l}\text { Severe weather events } \\
\text { lead to re-pricing of } \\
\text { sovereign debt }\end{array}$ & $\begin{array}{l}\text { Severe weather } \\
\text { events impact } \\
\text { business continuity }\end{array}$ \\
\hline \multirow{5}{*}{ Transition risk } & $\begin{array}{l}\text { Tightening energy efficiency } \\
\text { standards impact property } \\
\text { exposures;Stranded assets impair loan } \\
\text { portfolios;Disruptive technology leads } \\
\text { to auto finance losses }\end{array}$ & $\begin{array}{l}\text { Tightening } \\
\text { climate-related policy } \\
\text { leads to repricing of } \\
\text { securities and derivatives }\end{array}$ & $\begin{array}{l}\text { Changing sentiment on } \\
\text { climate issues leads to } \\
\text { reputational risks }\end{array}$ \\
\hline
\end{tabular}

Source: [13].

\subsection{Identifying Material Exposures and Disclosure of Key Metrics}

In some jurisdictions, banks are now expected to adopt a comprehensive and strategic approach to managing their climate change risks. The PRA, for instance, has already published a Supervisory Statement, providing regulatory guidelines for banks to enhance their approaches to managing their climate-related financial risks [14]. As per this supervisory statement, the PRA now explicitly requires banks to identify how financial risks from climate change may affect their business model and to include any material exposures relating to the financial risks from climate change in their ICAAPs. Banks are also explicitly expected to explain how they have determined what constitutes a material exposure in the context of their business models.

On the other hand, public disclosure of the potential climate-related risks and opportunities is now a key regulatory expectation in some countries, as per the TCFD recommendations. Accordingly, regulatory authorities in some jurisdictions have already started to harden their stance on climate change reporting. While there are different means through which this information can be disclosed, the TCFD's recommendation to corporations is to disclose relevant climate-related financial information in their public annual reports.

Given the comprehensive, practical, and flexible nature of the TCFD framework for corporate disclosure of climate-related risks and opportunities, it is expected to gain more popularity over time. In fact, TCFD's most recent status report indicates that the average number of recommended disclosures per company already increased by around 30\% between 2016 and 2018. In some G20 countries, disclosure of material climate risks in financial reports has already been introduced as a legal obligation. For instance, in the UK, all listed companies and large asset owners are now expected to report climate risks by 2022 [55].

At the EU level, environment, social, and governance (ESG) disclosure and benchmark regulations were finalized in 2019 with the publication of the ESG disclosure regulation and low-carbon benchmarks regulation, which are the initiatives under the EBA's Sustainable Finance Action Plan. The plan requires banks to actively identify and manage their climate-related risks, and disclose their key metrics, starting from 2021 [51]. There is a common understanding that improving their ESG rating is expected to help banks reduce their funding costs. However, consistent measurement of ESG remains a big challenge and a common taxonomy is needed. The EU's Green Taxonomy and the Green Bond Standard are expected to help in this area.

Box 1 provides an indicative list of suggested climate risk disclosures based on TCFD's recommendations and the authors' own suggestions. One of the Task Force's key recommended disclosures relates to the resilience of an organization's strategy to different climate-related scenarios, including a $2{ }^{\circ} \mathrm{C}$ or lower scenario. Other disclosures include a mix of quantitative and qualitative information, such as an account of the firms' integration of climate risks into overall risk management frameworks, corporate targets with respect to climate risks, and metrics such as a firm's own carbon emissions and greenhouse gas metrics. 
Box 1. Indicative List of Quantitative and Qualitative List of Climate Risk Disclosures for Banks.

- Internal governance and board oversight

- Climate risk related risks and opportunities

- $\quad$ Resilience of bank's business strategy to climate-related scenarios

- Financial planning with respect to climate risks

- Integration into banks' overall risk management framework

- $\quad$ Processes to identify, assess, and manage climate risk disclosures

- Corporate targets with respect to climate risks

- Metrics such as a bank's own carbon emissions and greenhouse gas metrics

- Transition risks in the bank's lending and investment portfolio

- Physical risks to banks assets and investments

- $\quad$ Financing of green growth sectors

- Reputational risks with respect to climate risks

- Compliance with the ESG factors

- $\quad$ Level of lending to high-risk sectors

Source: Compiled from [12-14,16] by the authors.

\subsection{Assessing Capital Impact through Scenario Analysis and Stress Testing}

From a prudential standpoint, climate change requires firms to assess the related financial risks on their capital structure. This means that banks should monitor climate change risks on an ongoing basis to identify and assess potential threats in a timely manner, taking preventive action where necessary to ensure that their capital sources remain adequate to mitigate relevant risks. However, BCBS's aforementioned survey has revealed that the majority of members to the Committee have not factored, or have not yet considered factoring, the mitigation of climate-related risks into the prudential capital frameworks [46].

In the UK, banks are already expected to start preparing to incorporate climate-related risk factors in their risk modeling frameworks to understand the short- and long-term financial risks to their business model and capital adequacy. More specifically, the PRA expects banks to take into account quantitative and qualitative metrics to monitor their exposure to climate change risks and to include any material climate-related financial risks in their ICAAPs. The PRA also expects banks to use stress testing within their ICAAPs to ensure their climate change-related exposures are covered by a commensurate amount of capital. The regulator is not prescriptive. However, it requires banks to develop their own scenarios and to calibrate them based on the general practice and experience in the industry [14].

The broad expectation from banks is to identify the factors that may impair asset values, increase credit risks, and reduce the value of their investments. In terms of physical risk scenarios, banks may consider mortgage lending in risky geographies against severe natural disaster scenarios and related simulations. Regarding transition risk scenarios, on the other hand, they can stress test their lending portfolios to energy, transportation, and industrial sectors, as well testing their trading positions under various stress scenarios. However, it remains a major challenge for banks to identify indicative types of data that they can use in undertaking granular financial analysis. For instance, BCBS's survey has shown that data availability is one of the main operational challenges in assessing climate-related financial risks [46].

The EBA's Action Plan on Sustainable Finance proposes to develop dedicated climate change stress tests. However, specific details have not been published as of early 2020 [51]. Specific requirements and variables with respect to stress scenarios are likely to differ depending on the assessment of the national regulators. However, climate-related scenario analysis is expected to be used more actively by banks to identify lending portfolio sensitivity to both physical and transition risks.In the UK, for instance, BoE's plan is to use certain variables with respect to rising temperatures, weather variability, and sea 
level rise to assess the resilience of the business models of the largest banks, insurers, and the financial system to the physical and transition risks of climate change [15].

Table 7 summarizes the indicative stress testing scenario variables proposed by the BoE as part of its planned climate change stress tests under 2021 Biennial Exploratory Scenario (BES), which will be the first comprehensive assessment of the UK financial system's exposure to climate-related risks.

Table 7. Bank of England's Indicative Scenario Variables.

\begin{tabular}{|c|c|c|c|}
\hline \multicolumn{2}{|c|}{ Climate Risk Variables } & \multicolumn{2}{|c|}{ Macrofinancial Variables } \\
\hline Physical variables & Transitional variables & Macroeconomic variables & Financial market variables \\
\hline 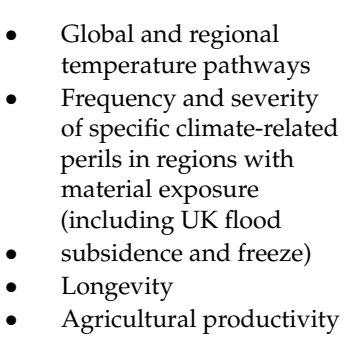 & $\begin{array}{ll}\text { - } & \text { Carbon price pathways } \\
\text { Emissions pathways } \\
\text { (aggregate, } \\
\text { and decomposed into } \\
\text { world regions } \\
\text { and sectors) } \\
\text { Commodity and energy } \\
\text { prices (including } \\
\text { renewables), by } \\
\text { fuel type } \\
\text { Energy mix }\end{array}$ & $\begin{array}{ll}\text { - } & \text { Real GDP (aggregate and } \\
\text { - } & \text { decomposed by sector) } \\
\text { - } & \text { Inflation } \\
\text { - } & \text { Central bank rates } \\
\text { - } & \text { Corporate profits } \\
\text { (aggregate and } \\
\text { decomposed by sector) } \\
\text { - } \quad \text { Household income } \\
\text { - } \quad \text { Residential and } \\
\text { commercial property prices }\end{array}$ & $\begin{array}{l}\text { - } \quad \text { Government bond yields } \\
\text { for major economies } \\
\text { - } \quad \text { Corporate bond yields for } \\
\text { major economies } \\
\text { (investment grade and } \\
\text { high yield) } \\
\text { - } \quad \text { Equity indices } \\
\text { - } \\
\text { Exchange rates. } \\
\text { Bank Rate }\end{array}$ \\
\hline
\end{tabular}

Source: [15].

As can be seen from the table, the variables include both climate and macrofinancial variables that the BoE proposed under its BES scenarios. The table suggests, in particular, that banks with exposure to clients in energy and transportation sectors, where the transition to a lower-carbon economy may have a substantial impact on banks' business models, should particularly take into account the risk of reduced earnings and business disruption. Given that the BCBS's survey has shown that a large number of members identified difficulties in the mapping of transmission channels of climate-risks as the key operational challenge in assessing climate-related financial risks, the BES scenarios are important for other jurisdictions as well.

\section{Conclusions and Policy Implications}

This article reviewed the progress of regulations and supervisory approaches with respect to the management of financial risks from climate change. As discussed in the article, despite intensifying climate risks, only a handful of banking regulators across the world have started to introduce regulations. However, as climate-related financial risks continue to receive increasing attention, regulatory authorities in other jurisdictions are also be expected to set regulations with respect to banks' public disclosure, capital planning, and governance processes [59].

A number of implications emerge from this article. For instance, banks are expected to approach climate risk in the same way that they approach any other financial risks, ensuring that they manage their relevant exposures in a prudent manner. It is clear that banks are generally required to think holistically about how climate-related risks are identified and managed in terms of credit risk, operational risk, market risk, reputational risk, and beyond. In doing so, they are expected to consider the different ways that climate risks are likely to have an impact on their balance sheets, business strategies, and profitability.

Although the development of regulations is still in progress across the world, this does not mean that banks can be complacent. For instance, the EBA explicitly expects banks to act on climate-related risks as soon as possible, rather than waiting for the related rules to be finalized. As pointed out in this article, certain regulatory expectations are now more or less identified in some jurisdictions. These include regulations and supervisory expectations ranging from banks' internal governance and board-level attention to climate risks to scenario analysis and stress testing.

Therefore, banks should start adopting climate risks into their governance structures, business strategies, and risk management frameworks, particularly adopting climate scenarios to understand 
their exposure to climate-related risks, including both physical and transition risks. A good starting point for banks will be to start assessing the climate change risks in their asset portfolios, outsourcing arrangements and loan portfolios.

Banks should particularly focus on the capital impact of climate risks using scenario analysis and stress testing. As pointed out in the article, in the UK, the PRA has already provided high-level guidelines on how banks should conduct scenario analyses to assess the impact of financial risks arising from climate change. This means that banks in other jurisdictions now have a concrete example and guidelines to follow.

On the other hand, the onus will be on banks to identify metrics that provide transparency on the impact of climate-related risks on their balance sheets and business models. A key challenge will be to determine which risk factors are material and to articulate to the supervisory authorities as to how they have done so in the context of their business. Likewise, it will be banks' responsibility to assess if they should disclose additional information on their climate change-related financial risks.

A key ongoing initiative is the EU's move towards more sustainable finance. As discussed in the article, the EBA's Action Plan provides clarification on where action is needed from banks. However, the EBA is expected to publish further discussion papers, technical standards, and further guidance across its ESG mandates from 2020 to 2025. This will be important also for banks in non-EU jurisdictions, as they are likely to cover details with respect to key metrics, scenario analysis, and adjustments to risk weights.

With a responsibility to consider the physical, transition, and liability climate-related risks facing their business, boards will also need to start thinking about what kind of controls they need to have in place across the internal risk frameworks. Therefore, banks should start getting their wider governance framework in place, ensuring that their boards have the appropriate level of oversight and challenge with clear climate-related reporting lines and respective responsibilities.

Author Contributions: Conceptualization, M.F. and H.G.; methodology, M.F. and H.G.; resources, M.F. and H.G.; writing_-original draft preparation, M.F. and H.G.; writing_review and editing, M.F. and H.G.; visualization, M.F. and H.G.; supervision, M.F. and H.G.; project administration, M.F. and H.G. All authors have read and agreed to the published version of the manuscript.

Funding: This research received no external funding.

Conflicts of Interest: Mete Feridun is formerly a regulatory risk and strategy consultant at PwC UK, as well as a senior regulator at the Prudential Regulation Authority, Bank of England and the Financial Conduct Authority. Hasan Güngör is currently a Member of the Board of Directors at Kıbrıs İktisat Bankası Ltd. However, the opinions expressed in this article are those of the authors and do not purport to reflect the opinions or views of their current or former institutions.

\section{Appendix A. The Prudential Regulation Authority's Survey on the Impact of Climate Change on the UK Banking Sector (for Details See [14]).}

(1). Current impacts of climate-related risk

(1a) Within your organization's current business planning horizon, what climate-related risks have you identified in relation to:

i. the achievement of your firm's business plan;

ii. the continued safety and soundness of your firm; and/or

iii. the protection of your shareholders/investors/deposit holders.

Please let us know the duration of your current business planning horizon: years

Please list your top three to five risks arising from climate change.

(1b) Has your organization assessed the likelihood and impact of these climate risks? YES/NO

If yes, please provide further details, including the timescale over which risks have been assessed.

(1c) Are there specific business activities, asset classes, and/or geographies, within your organization that will be more affected by climate change than others (e.g., loan book, trading book)? YES/NO 
If yes, please provide further details.

(1d) Has your organization undertaken any granular, quantified analysis on the potential impact of climate-related risks on your assets, both for:

- Assets linked to sectors and projects with high carbon business models to estimate potential losses in the event of a rapid transition to a lower carbon economy (i.e., transition risk)? YES/NO

- Assets linked to sectors, regions, and clients particularly vulnerable to climate-related events, such as storms, floods, or drought? (YES/NO) If yes, please provide further information.

(2) Future impacts of climate-related risk

(2a) Beyond your existing business plan horizon (as indicated in 1a), has your organization evaluated the longer-term impact of climate-related risk on your business model, safety and soundness of your firm, and to policyholders? YES/NO

If yes, please provide further information below, including how the risks differ, if at all, from those identified in Question 1 and the future timescale(s) over which these risks have been considered.

(2b) If you have not done so as part of question (2a), please consider climate-related risks that may arise by 2030. In doing this, please include how these 2030 risks differ, if at all, from those identified in Question 1.

(3) Governance and management of climate-related risks

(3a) Please describe your organization's approach to managing climate-related risks. Within this, the PRA would welcome further information relating to climate-risk governance and strategy, including board oversight, as well as your approach to risk management and the use of targets and metrics.

(3b) If not covered in (3a), does your organization have a specific document outlining its strategic response to climate change? YES/NO

(3c) Please provide any further information on approaches you find particularly effective for assessing and managing climate-related risks (e.g., stress testing or scenario analysis).

(4) The role of the banking industry and banking regulators.

(4a) What do you consider to be the role of the banking industry in supporting an orderly, market transition to a lower carbon economy? Within this, please include any further information on your firm's activities in green finance, such as green bonds.

(4b) What do you consider to be the role of banking regulators in supporting an orderly, market transition to a lower carbon economy?

\section{Appendix B. Stock Take Questionnaire Conducted by the Basel Committee's Task Force on Climate-Related Financial Risks (for Details See [56]).}

Question 1: the role of climate-related risks in the regulatory and supervisory framework

Are climate-related risks specifically designated in your regulatory and supervisory framework?

Are they implicitly covered? If so, please describe the way in which such risks are reflected in your framework, giving citations where possible, and whether the mandate of your institution explicitly covers such risks. Are there specific challenges or barriers that prevent you from considering climate-related risks?

Question 2: the measures taken to raise awareness of climate-related risks

Has your institution raised climate-related risks in discussions with banks and/or through public channels? If so, please describe the issues raised and the channels used.

Question 3: research related to the measurement of climate-related risks

Has your institution conducted any research related to the measurement of financial risks related to climate change, including analytical tools and models to assess physical and transitional risks related to climate change at a micro- and macro-level? If so, please describe the research conducted (including the data sources used and analytical approaches) and a link to the work, if published. 
Question 4: banks' views on the impact of climate-related risks and their approaches to managing such risks

Have you surveyed banks on:

(i) their views on the financial impact of climate-related risks; and

(ii) how they manage such risks? If yes, please describe the main takeaways from this work, including: (i) the role of the board of directors in discussing climate-related risks; and (ii) the data and methodologies used by banks in modeling the impact of climate-related financial risks.

Question 5: supervisory guidance/expectations related to banks' management of climaterelated risks

Has your institution issued supervisory guidance related to the expected governance, strategy, and/or risk management of climate-related risks by banks? If so, please describe the main elements of this guidance.

Question 6: banks' disclosure of climate-related risk information

Do banks in your jurisdiction disclose or discuss climate-related financial risks (e.g., governance, strategy, risk management, and/or metrics and targets)? If so, please describe the main elements of these disclosures. Are these disclosures voluntary or a result of supervisory expectations/requirements? Does your institution provide a taxonomy to be used for these disclosures?

Question 7: current or planned consideration of climate risk-related initiatives with respect to the prudential framework

Has your institution factored, or considered factoring, the mitigation of climate-related risks into its prudential framework? If so, please describe how you have factored this mitigation.

Question 8: other initiatives underway related to climate-related risks.

What other initiatives are underway in your institution on climate-related risks?

\section{References}

1. Network of Central Banks and Supervisors for Greening the Financial System (NGFS). Guide for Supervisors: Integrating Climate-Related and Environmental Risks into Prudential Supervision. 2020. Available online: https://www.ngfs.net/sites/default/files/medias/documents/ngfs_guide_for_supervisors.pdf (accessed on 27 May 2020).

2. Feridun, M. What do the Evolving Prudential Regulations on Climate Change Risks Mean for Banks? Oxford Business Law Blog. 2020. Available online: https://www.law.ox.ac.uk/business-law-blog/blog/2020/01/whatdo-evolving-prudential-regulations-climate-change-risks-mean (accessed on 24 January 2020).

3. Klomp, J. Financial fragility and natural disasters: An empirical analysis. J. Financ. Stab. 2014, 13, 180-192. [CrossRef]

4. Noth, F; Schüwer, U. Natural Disaster and Bank Stability: Evidence from the US Financial System. State Administration of Foreign Exchange: Beijing, China, 2018.

5. Dafermos, Y.; Nikolaidi, M.; Galanis, G. Climate change, financial stability and monetary policy. Ecol. Econ. 2018, 152, 219-234. [CrossRef]

6. Cui, Y.; Geobey, S.; Weber, O.; Lin, H. The impact of green lending on credit risk in China. Sustainability 2018, 10, 2008. [CrossRef]

7. Huang, B.; Punzi, M.T.; Wu, Y. Do Banks Price Environmental Risk? Evidence from a Quasi Natural Experiment in the People's Republic of China; Asian Development Bank Institute: Tokyo, Japan, 2019; No: 974.

8. Caldecott, B.; Harnett, E.; Cojoianu, T.; Kok, I.; Pfeiffer, A. Stranded Assets: A Climate Risk Challenge; Inter-American Development Bank: Washington, DC, USA, 2016.

9. Roncoroni, A.; Battiston, S.; Escobar Farfàn, L.O.L.; Martínez, J.S. Climate Risk and Financial Stability in the Network of Banks and Investment Funds. Available online: https://ssrn.com/abstract=3356459 (accessed on 19 March 2019).

10. Feyen, E.H.; Utz, R.J.; Zuccardi Huertas, I.E.; Bogdan, O.; Moon, J. Macro-Financial Aspects of Climate Change; World Bank Group: Washington, DC, USA, 2020; No: 9109. 
11. Campiglio, E.; Monnin, P.; von Jagow, A. Climate Risks in Financial Assets; Council on Economic Policies: Zurich, Switzerland, 2019.

12. Prudential Regulation Authority (PRA). CP 23/18: Enhancing Banks' and Insurers' Approaches to Managing the Financial Risks from Climate Change. 2018. Available online: https: //www.bankofengland.co.uk/prudential-regulation/publication/2018/enhancing-banks-and-insurersapproaches-to-managing-the-financial-risks-from-climate-change (accessed on 15 October 2018).

13. Prudential Regulation Authority (PRA). Transition in Thinking: The Impact of Climate Change on the UK Banking Sector, September 2018. Available online: https://www.bankofengland.co.uk/-/media/boe/files/ prudential-regulation/report/transition-in-thinking-the-impact-of-climate-change-on-the-uk-bankingsector.pdf (accessed on 28 September 2018).

14. Prudential Regulation Authority (PRA). SS3/19: Enhancing Banks' and Insurers' Approaches to Managing the Financial Risks Arising from Climate Change, April 2019. Available online: https://www.bankofengland. co.uk/-/media/boe/files/prudential-regulation/supervisory-statement/2019/ss319 (accessed on 20 April 2020).

15. Bank of England. The 2021 Biennial Exploratory Scenario on the Financial Risks from Climate Change; A Discussion Paper; Bank of England: London, UK, 2019.

16. Task Force on Climate-Related Financial Disclosures (TCFD). Recommendations of the Task Force on Climate-Related Financial Disclosures. 2017. Available online: https://www.fsb-tcfd.org/wp-content/ uploads/2017/06/FINAL-2017-TCFD-Report-11052018.pdf (accessed on 20 April 2020).

17. United Nations Environment Programme Finance Initiative (UNEP FI). Global Climate Change: Risk to Bank Loans. 2006. Available online: https:/www.unepfi.org/fileadmin/documents/global_climate_change_ risk.pdf (accessed on 20 April 2020).

18. Ceronsky, M.D.; Anthoff, C.H.; Tol, R.S.J. Checking the Price Tag on Catastrophe: The Social Cost of Carbon under Non-Linear Climate Response; ESRI Working Paper No. 392; ESRI: Redlands, CA, USA, 2011; Available online: https://www.esri.ie/system/files?file=media/file-uploads/2015-07/WP392.pdf (accessed on 20 April 2020).

19. Hale, G. What Are the Financial Risks from Climate Change? 2020. Available online: https://econofact.org/ what-are-the-financial-risks-from-climate-change (accessed on 13 April 2020).

20. Farid, M.; Keen, M.; Papaioannou, M.; Parry, I.; Pattillo, C.; Ter-Martirosyan, A. After Paris: Fiscal, Macroeconomic, and Financial Implications of Climate Change; International Monetary Fund: Washington, DC, USA, 2016; Volume 16.

21. Hoepner, A.G.; Wilson, J.O.S. Social, environmental, ethical and trust (SEET) issues in banking: An overview. In Research Handbook on International Banking and Governance; Barth, J.R., Lin, C., Wihlborg, C., Eds.; Edward Elgar.: Cheltenham, UK, 2010; pp. 427-457.

22. Hu, V.I.; Scholtens, B. Corporate social responsibility policies of commercial banks in developing countries. Sustain. Dev. 2014, 22, 276-288. [CrossRef]

23. Kapoor, S.; Sandhu, H.S. Does it pay to be socially responsible? An empirical examination of impact of corporate social responsibility on financial performance. Glob. Bus. Rev. 2010, 12, 185-208. [CrossRef]

24. Khan, H.U.Z.; Halabi, A.K.; Samy, M. Corporate social responsibility (CSR) reporting: A study of selected banking companies in Bangladesh. Soc. Responsib. J. 2009, 5, 344-357. [CrossRef]

25. Krasodomska, J. CSR disclosure in the banking industry. Empirical evidence from Poland. Soc. Responsib. J. 2015, 11, 406-423. [CrossRef]

26. Scholtens, B. Corporate social responsibility in the international banking industry. J. Bus. Ethics 2009, 82, 159-175. [CrossRef]

27. Weber, O.; Diaz, M.; Schwegler, R. Corporate social responsibility of the financial sector-Strengths, weaknesses and the impact on sustainable development. Sustain. Dev. 2014, 22, 321-335. [CrossRef]

28. Wu, M.W.; Shen, C.H. Corporate social responsibility in the banking industry: Motives and financial performance. J. Bank. Financ. 2013, 37, 3529-3547. [CrossRef]

29. Georgopoulou, E.; Mirasgedis, S.; Sarafidis, Y.; Hontou, V.; Gakis, N.; Lalas, D.; Xenoyianni, F.; Kakavoulis, N.; Dimopoulos, D.; Zavras, V. A methodological framework and tool for assessing the climate change related risks in the banking sector. J. Environ. Plan. Manag. 2015, 58, 874-897. [CrossRef]

30. Thompson, P.; Cowton, C.J. Bringing the Environment into Bank Lending: Implications for Environmental Reporting. Br. Account. Rev. 2004, 36, 197-218. [CrossRef]

31. Weber, O.; Fenchel, M.; Scholz, R. Empirical Analysis of the Integration of Environmental Risks into the Credit Risk Management Process of European Banks. Bus. Strategy Environ. 2008, 17, 149-159. [CrossRef] 
32. Sharfman, M.P.; Fernando, C.S. Environmental Risk Management and the Cost of Capital. Strateg. Manag. J. 2008, 29, 569-592. [CrossRef]

33. El Ghoul, S.; Guedhami, O.; Kwok, C.C.; Mishra, D.R. Does Corporate Social Responsibility Affect the Cost of Capital? J. Bank. Financ. 2011, 35, 2388-2406. [CrossRef]

34. Campbell, D.; Slack, R. Environmental Disclosure and Environmental Risk: Sceptical Attitudes of UK Sell-side Bank Analysts. Br. Account. Rev. 2011, 43, 54-64. [CrossRef]

35. Goss, A.; Roberts, G.S. The Impact of Corporate Social Responsibility on the Cost of Bank Loans. J. Bank. Financ. 2011, 35, 1794-1810. [CrossRef]

36. Furrer, B.; Hamprecht, J.; Hoffmann, V.H. Much Ado about Nothing? How Banks Respond to Climate Change. Bus. Soc. 2012, 51, 62-88. [CrossRef]

37. Nandy, M.; Lodh, S. Do Banks Value the Eco-Friendliness of Firms in their Corporate Lending Decision? Some Empirical Evidence. Int. Rev. Financ. Anal. 2012, 25, 83-93. [CrossRef]

38. Weber, O. Environmental Credit Risk Management in Banks and Financial Service Institutions. Bus. Strategy Environ. 2012, 21, 248-263. [CrossRef]

39. Delis, M.D.; de Greiff, K.; Ongena, S. Climate policy risk and the pricing of bank loans. Swiss Finance Institute: Geneva, Switzerland. In Climate Policy Risk and the Pricing of Bank Loans (April 21, 2019); EBRD Working Paper, (231); EBRD: London, UK, 2019.

40. Monasterolo, I.; Battiston, S.; Janetos, A.; Zheng, Z. Vulnerable yet relevant: The two dimensions of climate-related financial disclosure. Clim. Chang. 2017, 145, 495-507. [CrossRef]

41. Christophers, B. Climate change and financial instability: Risk disclosure and the problematics of neoliberal governance. Ann. Am. Assoc. Geogr. 2017, 107, 1108-1127. [CrossRef]

42. Goldsmith-Pinkham, P.S.; Gustafson, M.; Lewis, R.; Schwert, M. Sea Level Rise and Municipal Bond Yields, October 2019. Available online: https://rodneywhitecenter.wharton.upenn.edu/wp-content/uploads/2019/12/ 09-19.Schwert.pdf (accessed on 13 April 2020).

43. Heinkel, R.; Kraus, A.; Zechner, J. The effect of green investment on corporate behavior. J. Financ. Quant. Anal. 2001, 36, 431-449. [CrossRef]

44. Flammer, C. Corporate green bonds. J. Financ. Econ. Forthcom. 2018. [CrossRef]

45. Ouazad, A.; Kahn, M.E. Mortgage Finance in the Face of Rising Climate Risk (No. w26322); National Bureau of Economic Research: New York, NY, USA, 2019.

46. Basel Committee on Banking Supervision (BCBS). Climate-Related Financial Risks: A Survey on Current Initiatives. 2020. Available online: https://www.bis.org/bcbs/publ/d502.pdf (accessed on 30 April 2020).

47. Network of Central Banks and Supervisors for Greening the Financial System (NGFS). NGFS Guides Central Banks and Supervisors towards Better Management of Climate-Related and Environmental Risks. 2020. Available online: https://www.ngfs.net/en/communique-de-presse/ngfs-guides-central-banks-andsupervisors-towards-better-management-climate-related-and (accessed on 27 May 2020).

48. United Nations Environment Programme Finance Initiative (UNEP FI). Extending our Horizons: Assessing Credit Risk and Opportunity in a Changing Climate, April 2018. Available online: https://www.unepfi.org/ news/themes/climate-change/extending-our-horizons (accessed on 13 April 2020).

49. Georgieva, K. The Adaptive Age, Finance \& Development, December 2019. Available online: https://www.imf. org/external/pubs/ft/fandd/2019/12/pdf/climate-change-and-the-age-of-adaptation-georgieva.pdf (accessed on 13 April 2020).

50. Grippa, P.; Jochen, S.; Felix, S. Climate Change and Financial Risk, Finance \& Development, December 2019. Available online: https:/www.imf.org/external/pubs/ft/fandd/2019/12/climate-change-central-banks-andfinancial-risk-grippa.htm (accessed on 13 April 2020).

51. European Banking Authroity (EBA). Action Plan on Sustainable Finance. 2019. Available online: https: //eba.europa.eu/file/376050/download?token=oMDnkR18 (accessed on 6 December 2019).

52. Council of the European Union (CEU). A Proposal for a Regulation to Establish a Framework to Facilitate Sustainable Investment. 2019. Available online: https://eur-lex.europa.eu/legal-content/EN/TXT/PDF/?uri= CELEX:52018PC0353\&from=EN (accessed on 17 December 2019).

53. European Commission (EC). Commission Communication on the Sustainable Europe Investment Plan. 2020. Available online: https://ec.europa.eu/commission/presscorner/detail/en/fs_20_48 (accessed on 14 January 2020). 
54. Climate Financial Risk Forum (CFRF). Climate Financial Risk Forum guide 2020. 2020. Available online: https: //www.fca.org.uk/publication/corporate/climate-financial-risk-forum-guide-2020-summary.pdf (accessed on 30 June 2020).

55. HM Treasury. Green Finance Strategy. 2019. Available online: https://assets.publishing.service.gov.uk/ government/uploads/system/uploads/attachment_data/file/820284/190716_BEIS_Green_Finance_Strategy_ Accessible_Final.pdf (accessed on 15 June 2020).

56. Berenguer, M.; Cardona, M.; Evain, J. Integrating Climate-Related Risks into Banks' Capital Requirements, WWF, March 2020. Available online: https://www.i4ce.org/wp-core/wp-content/uploads/2020/03/ IntegratingClimate_EtudeVA.pdf (accessed on 20 April 2020).

57. Ens, E.; Johnston, C. Scenario Analysis and the Economic and Financial Risks from Climate Change, Staff Discussion Paper. 2020. Available online: https://www.bankofcanada.ca/wp-content/uploads/2020/05/ SDP-2020-3.pdf (accessed on 19 May 2020).

58. Wright, P. Climate Change and Prudential Regulation: Issues in New Zealand, the Treasury, June 2019. Available online: https://treasury.govt.nz/sites/default/files/2019-06/climate-change-background-paperpatricia-wright.pdf (accessed on 10 May 2020).

59. Feridun, M. "Basel V" Should Target the "Green Swan", Duke Law Global Financial Markets Center FinReg Blog. 2020. Available online: https://sites.duke.edu/thefinregblog/2020/05/21/basel-v-should-target-thegreen-swan (accessed on 21 May 2020).

(C) 2020 by the authors. Licensee MDPI, Basel, Switzerland. This article is an open access article distributed under the terms and conditions of the Creative Commons Attribution (CC BY) license (http://creativecommons.org/licenses/by/4.0/). 